UDC 616.12-005.4:616.132.2]-089

\title{
Fractional Flow Reserve-Guided Hybrid Coronary Revascularization in Multi-Vessel Coronary Arteries Disease
}

\author{
Stukov Y. Y., Rudenko S. A., Gavrylyshyn A. Yu., Rudenko M. L., Salo S. V., Rudenko A. V.
}

\author{
National M. M. Amosov Institute of Cardiovascular Surgery National Academy of the Medical Sciences \\ of Ukraine (Kyiv)
}

\begin{abstract}
Coronary artery bypass grafting without cardiopulmonary bypass (OPCABG) as a minimally invasive cardiac surgery (MICS) procedure has been used increasingly to treat coronary artery disease. We present our experience using off-pump minimally - invasive direct coronary artery bypass grafting (OPMIDCAB) and fractional flow reserve (FFR) - guided percutaneous coronary interventions (PCI) strategy for coronary revascularization.

Purpose. Presentation of our experience in FFR - guided hybrid coronary revascularization in patients with multi vessel coronary artery disease.

Conclusion. A hybrid procedure that changes a conventional CABG of all stenotic arteries, into a FFR - guided PCI is an appealing way to minimize the risk of complex heart surgery, combining positive outcomes of CABG along with low stent restenosis and thrombosis rates compared to venous grafts.

Key words: coronary artery bypass grafting, multi-vessel coronary disease, surgical revascularization, atherosclerosis, ischemic heart disease, hybrid coronary revascularization, off-pump coronary artery bypass grafting, percutaneous interventions, minimally invasive direct coronary artery bypass grafting, fractional flow reserve.
\end{abstract}

Coronary revascularization provides symptomatic relief from coronary artery disease (CAD) and improves short and long-term outcomes in patients with CAD. The optimal revascularization strategy is still controversial among interventional and conventional approaches for coronary revascularization, although coronary artery bypass grafting $(\mathrm{CABG})$ remains the standard of care for patients with three-vessel or left main coronary artery disease, since the use of CABG, as compared with percutaneous interventions (PCI), resulted in lower rates of the combined end point of major adverse cardiac or cerebrovascular events (MACE) at 1 year according to SYNTAX study (SYNergy Between PCI With TAXus and Cardiac Surgery). The optimal revascularization strategy should combine a minimally invasive surgical procedure that reduces perioperative risk, while maximizing long- term patency of conduit for CABG along with patient's survival rates.

Hybrid coronary revascularization (HCR) was first introduced in 1996 [1] as a promise to full coronary artery revascularization minimizing surgical trauma and adverse cardiovascular events. The initial concept was launched by Dr. Gianni from Imperial college of London and included small number of patients, who received favorable outcomes in terms of hospital stay, duration of extubation and 6-month period survival. The hybrid approach refers to the combination of CABG and PCI, namely providing anastomosis of left internal mammary artery (LIMA) to left anterior descending artery (LAD), typically via minimally invasive technique and PCI for remaining (non-LAD) vessels.
The rationale for HCR lies in the well-established survival benefit conferred by LIMA-to-LAD grafts and the use of new DES-stent platforms featuring low stent restenosis and thrombosis rates compared with venous graft stenosis and occlusion rates [2]. The superior patency of LIMAto-LAD graft provides prophylaxis against future proximal LAD lesions, which translates into better event-free survival and relief of angina. The benefits of bypassing other nonLAD coronary vessels are much less clear. Conduits for a non-LAD vessel may include other arterial grafts (complete arterial revascularization), but the saphenous vein is by far the most commonly used. A major limitation of CABG with great saphenous vein grafts (GSV) lies in the high graft failure rates with reports ranging from $13 \%$ to $29 \%$ at 1 year and up. Newer drug-eluting stent (DES) platforms with (e.g., everolimus-eluting stents (EES) or zotarolimus-eluting stents (ZES) or without (bioresorbable polymer-based or polymer-free stents) durable polymers show favorable outcomes, with 1-year target lesion revascularization (TLR) rates as low as 3\% to $3.25 \%$ [4]. Even in high-risk patients and complex lesions, ZES and EES maintain very low 1-year TLR rates of $4.4 \%$ and $4 \%$, respectively [5]. Thus, PCI and stenting provide strong competition for SVG revascularization because, unlike an LIMA-LAD graft, disease progression in the proximal native coronary segment occurs alongside GSV deterioration. Moreover, significant angiographic GSV stenosis occurs at least twice as frequently as in-stent restenosis using the latest technology platforms. Furthermore, even though GSV occlusion occurs at a 
higher rate compared with stent thrombosis, the clinical consequences of the latter are more dramatic, as it is more frequently associated with MACE [6] to $50 \%$ at 10 years after surgery [2].

The 2011 American College of Cardiology Foundation/ American Heart Association guidelines for CABG state that the "primary purpose of performing HCR is to decrease the morbidity rate of traditional CABG in high-risk patients". The role of the heart team in guiding appropriate patient selection for HCR is crucial [7]. All hybrid procedures are staged, the only distinction being the duration of the staging. For purposes of this discussion, 2-staged will be defined as PCI and CABG performed in 2 different operative suites, the 2 procedures separated by hours, days, or weeks, whereas 1-stop refers to hybrid HCR can be performed either simultaneously or as a "2-staged" procedure. The former implies concurrent $\mathrm{CABG}$ and $\mathrm{PCI}$ in a single operative suite, with PCI following CABG within minutes. In the "2-staged" approach, the optimal order-PCI first versus CABG first - is debated because each approach has advantages and disadvantages. Often, CABG is performed first, allowing the interventional cardiologist to study the LIMA - LAD graft before stent implantation. Thus, PCI to high-risk, non-LAD lesions is performed with a protected LAD territory. In case of unsuccessful stent implantation, surgical implantation remains an option. Additionally, the simultaneous HCR approach can be cost effective by reducing intensive care unit and general term length of stay. The two-stage HCR approach is recommended in highrisk patients with acute coronary syndrome in multi-vessel CAD with multiple comorbidities. In this case, stenting of symptom - related coronary artery performed followed by CABG.

Fractional flow reserve (FFR) utilizes a specialized guide wire to measure blood pressure within a

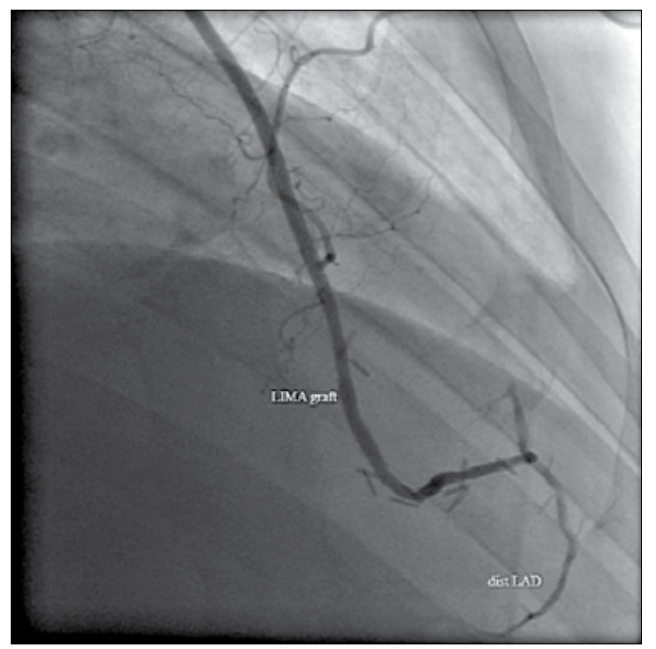

Fig. 1. LIMA to LAD graft patency check before $\mathrm{PCl}$ coronary artery. The original description of FFR required the induction of maximal hyperemia to achieve near linear correlation between coronary pressure and blood flow [8]. PCI guided by FFR was associated with a 54 percent reduction in the composite endpoint of death, myocardial infarction and urgent revascularization when compared to medical therapy alone, according to five-year data from the FAME 2 trial presented in May at EuroPCR 2018 and published simultaneously in the New England Journal of Medicine. Coronary physiology is an important tool that can guide management decisions for intermediate lesions and multivessel coronary artery disease (CAD), determining whether the patient would benefit from revascularization or medical therapy. Despite long-term data showing improved outcomes with FFR-guided decision-making, its use remains significantly underutilized in practice, with FFR being used in $6.1 \%$ of interventions for intermediate coronary lesions (40-70\% stenosis) [9]. FFR measurement is an effective way to determine which patients with stable angina may benefit from revascularization. Although, the use of FFR is most established among patients presenting with stable angina, revascularization of non-infarctrelated coronary arteries at the time of an acute myocardial infarction (AMI) remains controversial. Nevertheless, the concern is that patients with AMI may have multiple ruptured plaque and thus target lesions that may be underestimated by the use of FFR [10]. Recent evidence suggests that culprit lesions of patients presenting with a non-ST-segment elevation myocardial infarction (nonSTEMI) that were deferred based on a «negative» FFR have a relatively high event rate, calling into question the use of FFR in that patient population [11]. CAD:

Patient selection and indications for HCR in multi-vessel

1. A proximal complex LAD lesion with optimal distal anatomy amenable for LIMA - LAD grafting.

2. Non-LAD lesions amenable to PCI in patient with no contraindications to dual - antiplatelet therapy (DAPT).

3. High-risk of achieving "incomplete revascularization" with conventional CABG using median - sternotomy.

In the National institute of cardiovascular surgery we perform 2-stage HCR procedure. OPMIDCAB, followed by FFR - guided PCI.

\section{Method of hybrid surgery}

First stage - Coronary artery bypass grafting without cardiopulmonary bypass (OPCABG) as a minimally invasive cardiac surgery (MICS) - LIMA to LAD.

Second stage - on the third day following the surgery (after drain removing and stable hemostasis) - PCI.

PCI specificities - check LIMA-LAD patency (fig. 1). After that, following standard clinical protocol, FFR measurement with PCI on significant lesions (fig 2, a, b, c, d).

Conclusions. A hybrid procedure that changes a conventional CABG of all stenotic arteries, into a FFR - guided PCI is an appealing way to minimize the risk of complex 


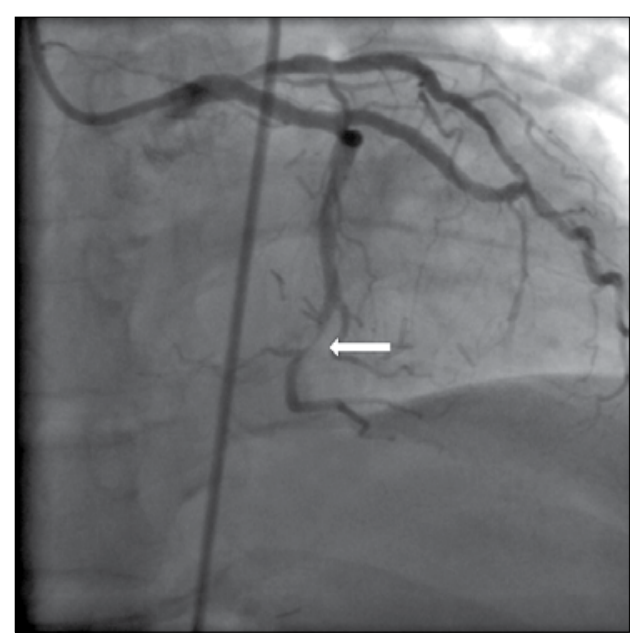

a)

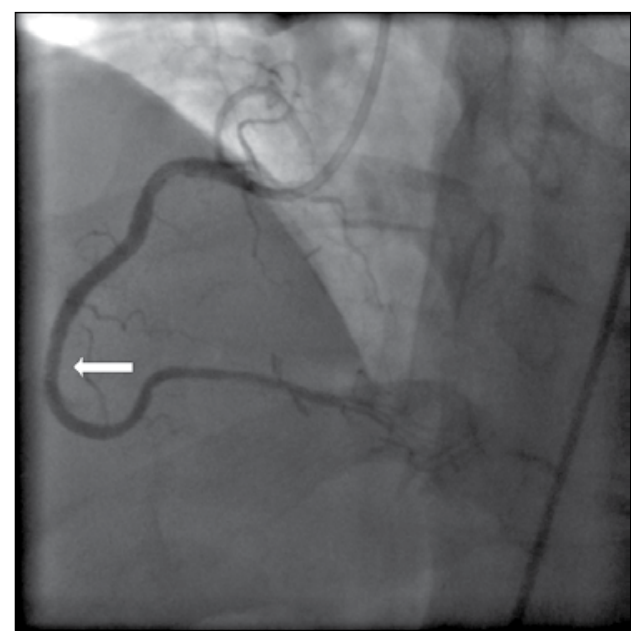

c)

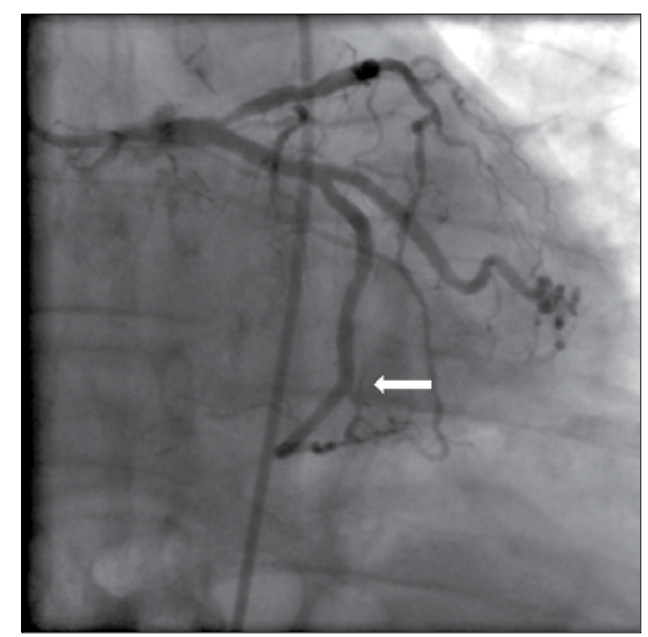

b)

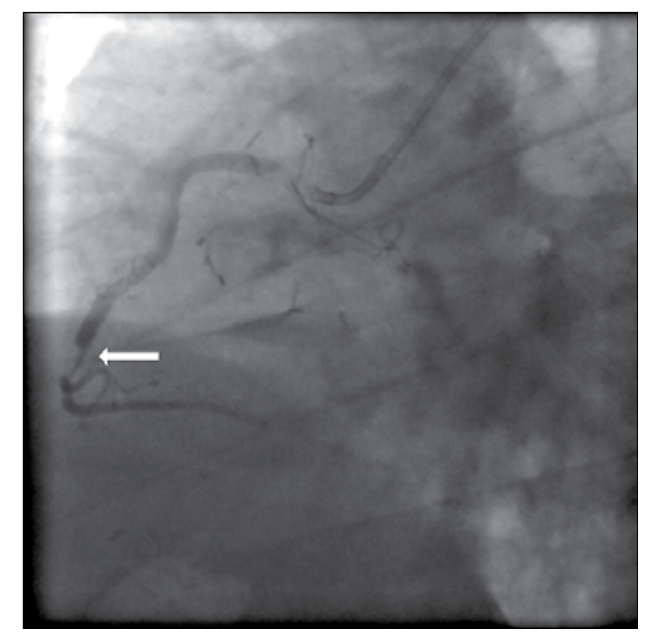

d)

Fig. 2. $P C I$ with FFR measurement: a) Baseline angio-significant stenosis of distal $C x$. b) $\mathrm{PCI}$ result on $\mathrm{Cx}-\mathrm{TIMI} 3$ flow. c) Baseline angio-significant stenosis of mid RCA.

d) $\mathrm{PCI}$ result on mid RCA - TIMI 3 flow.

heart surgery, combining positive outcomes of $\mathrm{CABG}$ along with low stent restenosis and thrombosis rates compared to venous grafts. Our report of a consecutive series of patients undergoing staged HCR demonstrates a low cumulative complication rate for a short length in intensive care unit and overall hospital stay. In selected institutions with a heart team comfortable for a staged approach of OPMIDCAB followed by FFR- based PCI may be an effective approach for selected patients with suitable coronary anatomy. Physiology-guided decision-making revascularization on nonLAD lesions adds objective evidence on improving clinical setting of CAD.

\section{References}

1. Gianni D. Angelini, Peter Wilde, Tomas A. Salerno, Giovanni Bosco, Antonia M. Calafiore Integrated left small thoracotomy and angioplasty for multivessel coronary artery revascularisation, The Lancet Volume 347, Issue 9003, 16 March 1996, Pages 757-758.

2. Vasileios F. Panoulas, Antonio Colombo, Alberto Margonato, Francesco Maisano, Hybrid Coronary Revascularization Promising, But Yet to Take Off, JOURNAL OF THE AMERICAN COLLEGE OF CARDIOLOGY, VOL. 65, NO. 1, 2015

3. Ralf E. Harskamp, Zhe Zheng, John H. Alexander, Judson B. Williams, Ying Xian, Michael E. Halkos, J. Matthew Brennan, Robbert J. de Winter, Peter K. Smith, Renato D. Lopes, Status Quo of Hybrid Coronary Revascularization for Multi-Vessel Coronary Artery Disease, Ann Thorac Surg. 2013 Dec; 96(6): 2268-2277.

4. Navarese EP, Tandjung K, Claessen B, et al. Safety and efficacy outcomes of first and second generation durable polymer drug eluting stents and biodegradable polymer biolimus eluting stents in clinical practice: comprehensive network meta-analysis. BMJ 2013;347:f6530. 
5. Stefanini GG, Serruys PW, Silber S, et al. The impact of patient and lesion complexity on clinical and angiographic outcomes after revascularization with zotarolimus- and everolimus-eluting stents: a substudy of the RESOLUTE All Comers Trial (a randomized comparison of a zotarolimuseluting stent with an everolimus-eluting stent for percutaneous coronary intervention). J Am Coll Cardiol 2011;57:2221-32.

6. Farooq V, Serruys PW, Zhang Y, et al. Shortterm and long-term clinical impact of stent thrombosis and graft occlusion in the SYNTAX Trial at 5 years: Synergy Between Percutaneous Coronary Intervention With Taxus and Cardiac Surgery Trial. J Am Coll Cardiol 2013;62:2360-9.

7. Head SJ, Kaul S, Mack MJ, et al. The rationale for Heart Team decision-making for patients with stable, complex coronary artery disease. Eur Heart J 2013;34:2510-8.
8. Evan Shlofmitz, DO; Allen Jeremias, MD, FFR in 2017: Current Status in PCI Management, online JACC, 2017.

9. Dattilo PB, Prasad A, Honeycutt E, Wang TY, Messenger JC. Contemporary patterns of fractional flow reserve and intravascular ultrasound use among patients undergoing percutaneous coronary intervention in the United States: insights from the National Cardiovascular Data Registry. J Am Coll Cardiol 2012;60:2337-9.

10. Vergallo R, Uemura S, Soeda T, et al. Prevalence and Predictors of Multiple Coronary Plaque Ruptures: In Vivo 3-Vessel Optical Coherence Tomography Imaging Study. Arterioscler Thromb Vasc Biol 2016;36:2229-38.

11. Hakeem A, Edupuganti MM, Almomani A, et al. LongTerm Prognosis of Deferred Acute Coronary Syndrome Lesions Based on Nonischemic Fractional Flow Reserve. J Am Coll Cardiol 2016;68:1181-91.

\title{
Функціональна гібридна реваскуляризація з вимірюванням фракційного коронарного кровотоку у пацієнтів із багатосудинним ураженням коронарних артерій
}

\author{
Стуков Ю. Ю., Руденко С. А., Гаврилишин А. Ю., Руденко М. Л., Сало С. В., Руденко А. В. \\ ДУ «Національний інститут серцево-судинної хірургії імені М. М. Амосова НАМН» (Київ)
}

Шунтування коронарних артерій без використання апарату штучного кровообігу з мінімально інвазивних доступів стає новим напрямом у хірургічному лікуванні ішемічної хвороби серця. У статті представлено досвід шунтування коронарних артерій без використання апарату штучного кровообігу з мінімально інвазивного доступу, поєднаного з гібридною реваскуляризацією з вимірюванням фракційного коронарного кровотоку та стентуванням функціонально значущих стенозів коронарних артерій. Комбінація хірургічної реваскуляризації з інтервенційним методом додає об'єктивні ознаки поліпшення клінічної картини у пацієнтів з ішемічною хворобою серця поряд із низьким рівнем рестенозу та тромбозу стентів II-III покоління порівняно з аутовенозними трансплантатами. Гібридна реваскуляризація проводиться у два етапи: першим етапом здійснюється шунтування передньої міжшлуночкової артерії (анастомоз LIMA-LAD), другим етапом (на третій день після екстракції дренажної трубки та надійного гемостазу) виконується інтервенційне втручання. Після ангіографічно підтвердженого функціонування шунта LIMA-LAD, згідно з локальним протоколом, виконується вимірювання фракційного коронарного кровотоку та стентування функціонально значущих стенозів коронарних артерій. Таким чином виконується подвійний контроль функціонування шунта: першим етапом в операційній - шляхом вимірювання швидкості кровотоку та відсутності судинного спротиву флоуметром, другим етапом - ангіографічно.

Мета роботи - представлення досвіду функціональної гібридної реваскуляризації шляхом вимірювання фракційного коронарного кровотоку у пацієнтів із мультисудинним ураженням коронарних артерій.

Висновки. Гібридна реваскуляризація міокарда змінює «стандартний» підхід до шунтування артерій із вираженим стенозом на реваскуляризацію з вимірюванням фракційного коронарного кровотоку та стентуванням функціонально значущих стенозів, що дає можливість знизити ризик операції на серці, поєднуючи беззаперечні переваги коронарного шунтування, поряд із низьким рівнем рестенозу та тромбозу, порівняно з використанням аутовенозних шунтів.

Ключові слова: аортокоронарне шунтування, мультисудинне ураження коронарних артерій, ішемічна хвороба серия, хірургічна реваскуляризація, атеросклероз, гібридна реваскуляризація, аортокоронарне шунтування без використання апарату штучного кровообігу, мінімально інвазивне шунтування коронарних артерій, фракційний коронарний кровотік. 